\section{Phallus indusiatus Vent. \& Pers. (Basidiomycetes) - a new generic record for Eastern Ghats of India}

\author{
Prasad Kumar Dash ${ }^{1}$, Deepak Kumar Sahu ${ }^{2}$, \\ Santilata Sahoo ${ }^{3}$ \& Ritarani Das ${ }^{3}$ \\ ${ }^{1}$ Biodiversity Conservation Division, Vasundhara, Bhubaneswar, \\ Orissa 751004, India \\ 2,3 P.G. Department of Botany, Utkal University, Bhubaneswar, \\ Orissa 751004, India \\ Email: ${ }^{2}$ pra.deepc83@gmail.com (corresponding author)
}

The floristic account of southern Orissa, often considered incomplete, was sporadically approached by Mooney, Gamble, Haines and subsequent workers. It provides an ideal background for further exploration and discovery of taxonomic novelties (Rout et al. 2007). An interesting macrofungus was collected from the foot hills of Kutrumali Hills in Koraput District of southern Orissa. Critical study of the material revealed it to be a hitherto unrecorded species from the Eastern Ghats (Lee 1957; Ainsworth et al. 1971; Alexopolous et al. 1996; Hemmes \& Desjardin 1999; Lockwood 2001; Martin 2002; Desjardin et al. 2004; Jamaluddin et al. 2004; Brown et al. 2006). The fungus, commonly called Long Net Stinkhorn, belongs to the order Phallales of the phylum Basidiomycotina.

Ecology and distribution: The fungus has been reported to grow at temperatures between 21 to $25^{\circ} \mathrm{C}$ in moist bamboo thickets at $300-600 \mathrm{~m}$ and relative humidity of $45-85 \%$ in tropical areas including Mexico, South America, Malaysia, Australia, southern China, Hong

Date of publication (online): 26 July 2010

Date of publication (print): 26 July 2010

ISSN 0974-7907 (online) | 0974-7893 (print)

Editor: V.B. Hosagoudar

Manuscript details:

Ms \# 02305

Received 07 September 2009

Finally accepted 29 June 2010

Citation: Dash, P.K., D.K. Sahu, S. Sahoo \& R. Das (2010). Phallus indusiatus Vent. \& Pers. (Basidiomycetes) - a new generic record for Eastern Ghats of India. Journal of Threatened Taxa 2(8): 1096-1098.

Copyright: (c) Prasad Kumar Dash, Deepak Kumar Sahu, Santilata Sahoo \& Ritarani Das 2010. Creative Commons Attribution 3.0 Unported License. JoTT allows unrestricted use of this article in any medium for non-profit purposes, reproduction and distribution by providing adequate credit to the authors and the source of publication.

Acknowledgements: We thank Concern India for providing financia support and Dr. Md. Nihal Aziz, Scientist, BSI, Kolkata for authenticating the identity of the specimen. Dr. Pratyush P. Mahapatra is acknowledged for photography.

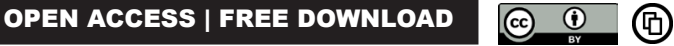

Kong and Japan. It is eaten as a vegetable in some parts of China and Hong Kong and the cost of dried mushroom is 10 to 20 US Dollar per kg. (Huang 2002).

This fungus was earlier collected from Sikkim \& Churra, Khasi Hills (Specimen collected by Hook.f. and deposited at CAL), on the ground Khandala, Maharashtra (collected by Blatter and deposited at BLAT); northern Bengal (collected by Hutchinson). Recent discovery of this fungus from the sacred grove forest of Kodagu District of Karnataka State in the Western Ghats (Bhagwat et al. 2005), Shimoga District of Karnataka (Swapna et al. 2008), forest floor of Santiniketan (Bakshi \& Mandal 2006) and presently from Kutrumali Hills of Koraput District of Orissa (Fig. 1) in the Eastern Ghats (P.K. Dash). The present collection reveals its extended distribution.

Nomenclature: Phallus indusiatus Vent. \& Pers., Syn. Meth. Fung. 244. 1801.

Phallus indusiatus was initially described by French naturalist Etienne Pierre Ventenat in 1798, before being placed in a new genus Dictyophora in 1809 by Desvaux and was known for many years as Dictyophora indusiata before being reclassified under its original name as Phallus indusiatus Vent. \& Pers.

Taxonomy: Phallus indusiatus has many common names based on its appearance, including long net stinkhorn, crinoline stinkhorn, basket stinkhorn; bridal veil fungus or veiled lady. This gives rise to its alternate common name of bamboo fungus or bamboo pith, and it is known as "Indrajal" among the tribals of Orissa. Phallus indusiatus Vent. \& Pers. is a partial saprobe (Ainsworth et al. 1971) growing on dead tree trunk and beneath the soil intermittently with the formation of reproductive structures called "eggs" (young stage of basidiocarp) with a conspicuous rhizomorph at the base existing in the substratum. The eggs are hypogeous when young and become epigeous at maturity (Alexopolous et al. 1996). The mature stinkhorn is up to $15 \mathrm{~cm}$ tall girded with a netlike structure, the indusium or 'skirt', which hangs down around $7 \mathrm{~cm}$ from the conical cap. The skirt's netlike openings are polyhedral or round in shape. The cap is 2-4 $\mathrm{cm}$ high and covered with a greenish-brown slime termed as "gleba". The stalk is $7-12 \mathrm{~cm}$ high and $0.2-0.5 \mathrm{~cm}$ in diameter. The matured basidiocarp is about $12-14 \mathrm{~cm}$ tall, receptacle white, $1.8-2.8 \mathrm{~cm}$ thick, cylindrical, spongy, perforated with bulbous base. Gleba (cap-fertile portion of basidiocarp) $1.8-2.8 \mathrm{~cm}$, dark metallic green and celled with an apical pore, sticky, gelatinous, odoriferous and decreasing with age. Indusium 8-12 cm in length, 8-30 $\mathrm{cm}$ in diameter, yellowish-white, porous, margin wavy, semi elastic and increasing with age; volva $2.4-2.8 \mathrm{~cm}$, white and thick. The life cycle of Phallus indusiatus is for 15-30 days, including vegetative (formation of mycelium) and reproductive (formation of basidiocarp) stages. 


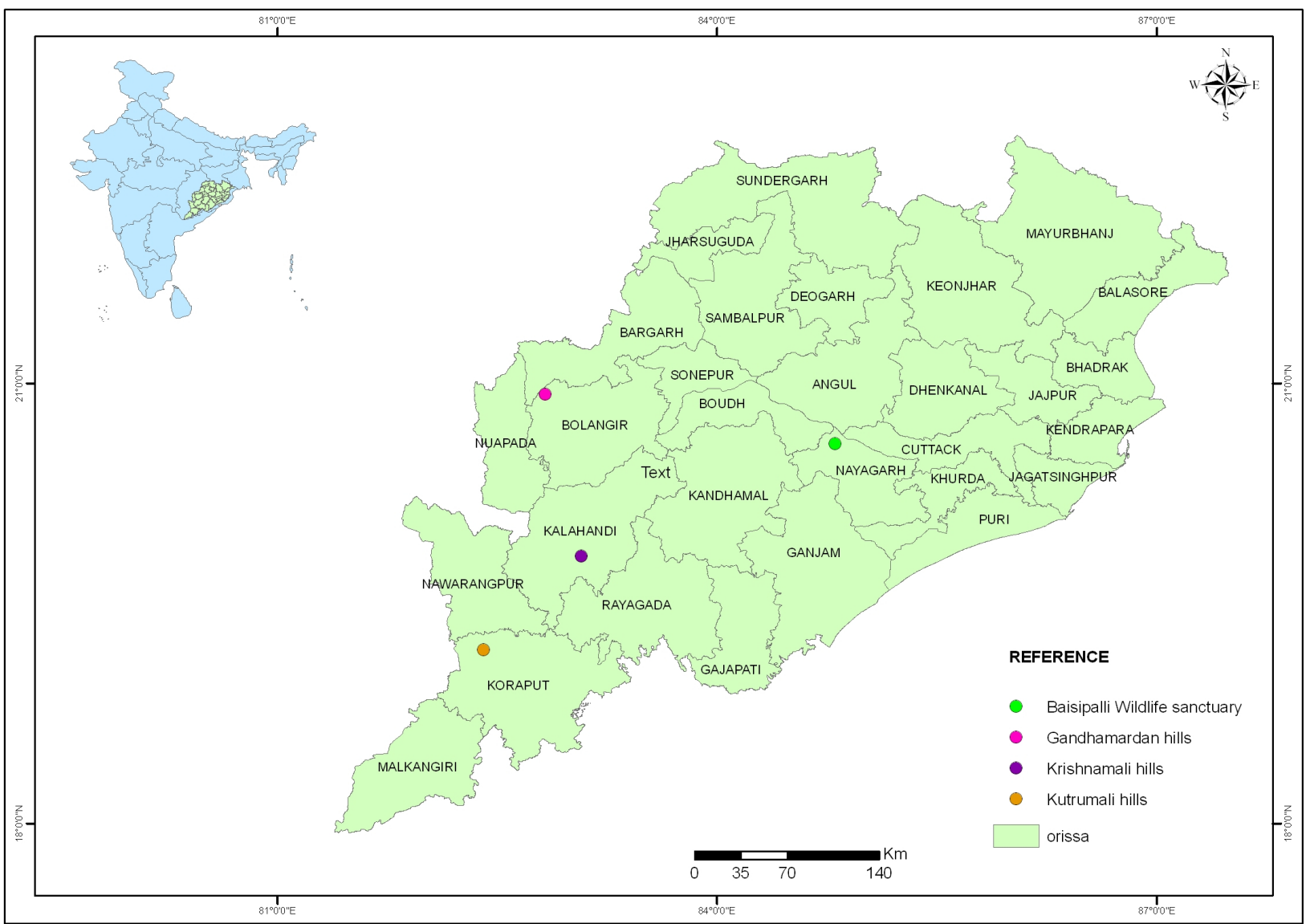

Figure 1. New locality records of Phallus indusiatus in Orissa

Their method of reproduction is different from many mushrooms, which use the air to spread their spores. Stinkhorns instead produce a sticky spore mass on their tip, which has a sharp, sickly-sweet odour of carrion to attract bees and flies. The mature fruiting bodies can be smelt from a considerable distance in the woods, and at close quarters most people find the cloying stink extremely repulsive. The flies land in the gleba and consume the slime, depositing it as excrement elsewhere. In older fungi the slime is eventually removed, the pale off-white bare pitted and ridge surface is exposed. The fruiting occurred during the months of October-November. To facilitate easy identification, the photograph is provided here (Image 1).

Present Collection: Field No. UU (F) 123-2008, Kutrumali, 19034'14.86”N \& 83011'23.89"E, 420m, coll. P.K. Dash, herbarium of PG Department of Botany, Utkal University, Bhubaneswar, Orissa.

Specimen examined: Dictyophora phalloidea Desv., Dehradun, FI. of northwestern Himalaya, McKinnon 1897 (Image 2) at Lower Plant Division, Central National Herbarium, CAL, Howrah, West Bengal.

Distribution in Orissa: The fungus was found to grow at an altitude of $420 \mathrm{~m}$ in a bamboo thicket near the foothill of Kutrumali (1903'27.61'N \& 82024'32.69”E) of Koraput
District in Orissa during post rainy season. The species was also observed in Krishnamali Hills (19041'46.40"N \& $83^{\circ} 4^{\prime} 38.97^{\prime \prime E)}$ of Karlapat Wildlife Sanctuary, and Kalahandi, Gandhamardan Hills (20048'09.1'N \& $82^{\circ} 491{ }^{\prime} 54.19$ "E) of Bolangir and Baisipalli Wildlife Sanctuary, Nayagarh District of Orissa at an altitude of 420 to $825 \mathrm{~m}$.

\section{REFERENCES}

Ainsworth, G.C., P.W. James \& D.L. Hawksworth (1971). Ainsworth and Bisby's Dictionary of the fungi, $6^{\text {th }}$ edition. Commonwealth Mycological Institute, Kew, 166pp.

Alexopolous, C.J., C.W. Mims \& M. Blackwell (eds.) (1996). Introductory Mycology. Wiley, New York, 544-554pp.

Bakshi, D \& N.C. Mandal (2006). Activities of some catabolic and anabolic enzymes of carbohydrate metabolism during developmental phases of fruit-bodies of Dictyophora indusiata and Geastrum fornicatum. Current science 90(8): 1062-1064.

Bhagwat, S.A., C.G. Kushalappa, P.H. Williams \& N.D. Brown (2005). The Role of Informal Protected Areas in Maintaining Biodiversity in the Western Ghats of India. Ecology and Society 10(1): 8 .

Brown, N., S. Bhagwat \& S. Watkinson (2006). Macrofungal diversity in fragmented and disturbed forests of the Western Ghats of India. Journal of Applied Ecology 43(1): 11-17. 


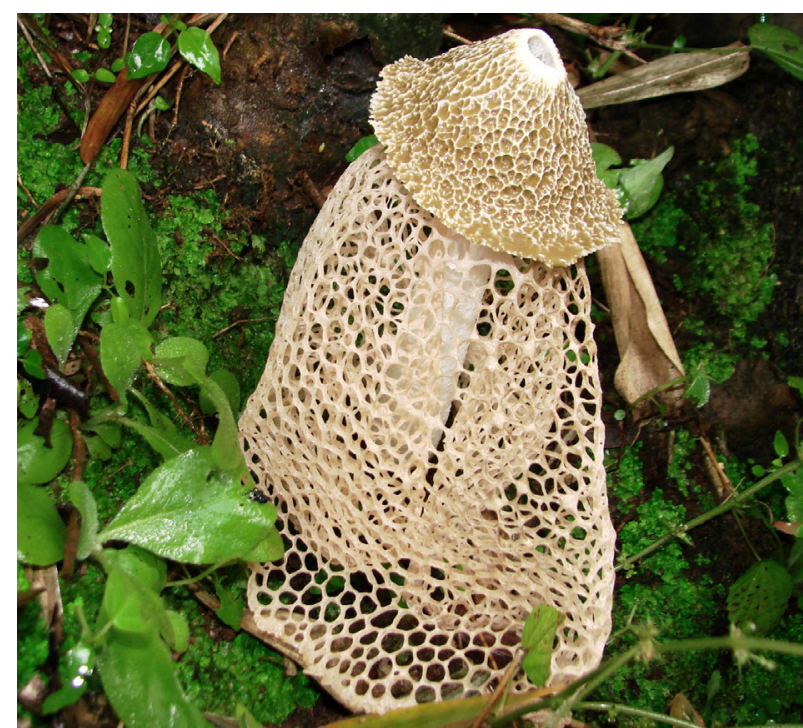

Image 1. Phallus indusiatus Vent. \& Pers.

Desjardin D.E., Z. Wang, M. Binder \& D.S. Hibbett (2004). Sparassis cystidiosa sp. nov. from Thailand is described using morphological and molecular data. Mycologia 96(5): 1010-1014.

Hemmes, D.E. \& D.E. Desjardin (1999). XVI International Botanical Congress, San Francisco, USA, 59pp.

Huang, N.L. (2002). Current status and future prospects of mushroom industry in China. Edible Fungi of China 107(19): 6-8.

Jamaluddin, M.G. Goswami \& B.M. Ojha (2004). Fungi of India, 1989-2001. Scientific Publishers (India), Jodhpur, 1-158pp.

Lee, W.S. (1957). Two new phalloids from Taiwan. Mycologia 49(1): $156-158$

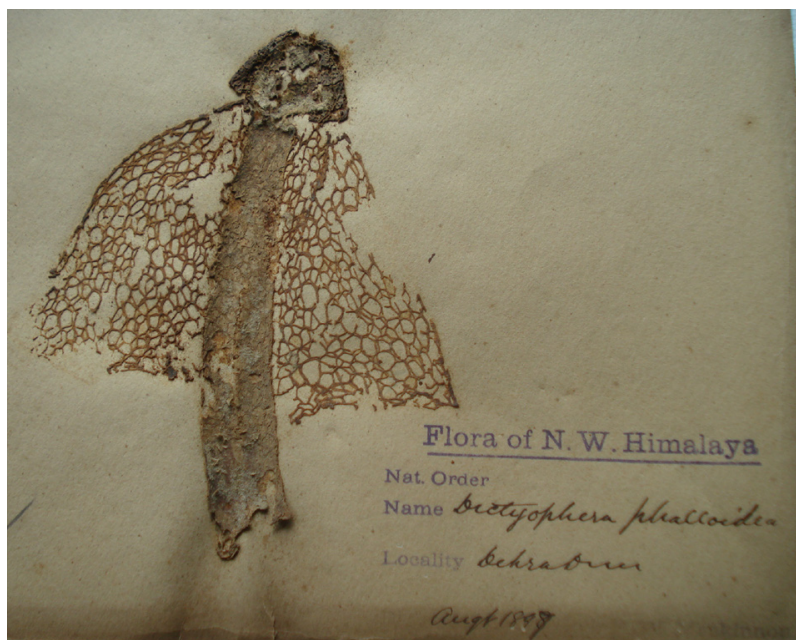

Image 2. Dictyphora phalloidea Desv.

Lockwood, T. F. (2001). Treasures from the Kingdom of Fungi: Featuring Photographs of Mushrooms and Other Fungi from Around the World). Mendocino, Korea: Taylor Lockwood Publisher, $127 \mathrm{pp}$

Martin, S. (2002). Fungi. Tropical tropics, No. 72. An interpretive newsletter for tourisim industry, Wet tropical management authority, The State of Queensland. Environmental Protection Agency, Australia.

Rout, N.C., N.K. Dhal, P.K. Dash \& A.K. Biswal (2008). Corallodiscus Batalin. (Gesneriaceae): a new generic record for Eastern Ghats, Orissa. Current science 95(1): 23-24.

Swapna, S., S. Abrar \& M. Krishnappa (2008). Diversity of macrofungi in semi-evergreen and moist deciduous forest of Shimoga District, Karnataka, India. Journal of Mycology and Plant Pathology 38(1): 21-26. 